\title{
TRAFFIC ENGINEERING ANALYSIS IN THE PREPARATION AND RECONSTRUCTION OF URBAN ROADS
}

\author{
Tibor SCHLOSSER ${ }^{1 *}$, Peter SCHLOSSER ${ }^{2}$
}

\section{Abstract}

The contribution deals with issues of road administration in municipalities in terms of the re-quirements for engineering renovations of urban communications networks. The goal is to de-clare an end to the degradation of the quality and service of local roads in cities. The reason is the lack of funding. The engineering analysis should demonstrate the need to make an informed request for reconstruction of local roads in our towns and cities. The aim of this paper is to describe the processes that are related to specific engineering work but are closely linked to the performance of the preparation on both sides, i.e., the administration versus the design. Why do we passively observe the gradual destruction of the quality of our local roads in the cities? Be-fore our eyes the road constructions of roadways crumble, on the other hand, the level of their transport service on them only presents us with traffic jams. How can you know the status of the background of our streets and their pavements in an urbanized area? A couple of technical studies oriented towards the advance of public transport, especially for Bratislava, the capital of Slovakia which were based on traffic modelling together with engineering designs were published (Borš et.al, 2017; Pomichal et.al, 2017; Koštial et.al, 2017; Schlosser and Schlosser, 2016; Schlosser and Orthová, 2016; Schlosser et.al, 2016; Schlosser et.al, 2017; Schlosser et.al, 2017). Some answers to the complexities of this issue are set out in this article.
Address

1 Slovak University of Technology in Bratislava, Slovakia, Faculty of Civil Engineering, Department of Transportation Engineering

2 DOTIS Consult, Ltd., Bratislava

* Corresponding author: tibor.schlosser@stuba.sk

\section{Key words}

- Traffic engineering,

- Urban roads,

- Sustained mobility.

\section{INTRODUCTION}

In Slovakia there are special problems with the flow and safety of the urban road transport and not just in the cities of Bratislava and Košice. Despite the general "economic crisis" in terms of our cities, the daily traveling of the citizens on the territory of cities is gradually collapsing, which is reflected in the quality of traffic flows. In addition, the degradation of the network of local urban roads requires op- erational or, in some cases, a long-term solution of the bypass routes themselves. Issues affecting the quality of life in larger urbanized areas, and in smaller towns and villages are already "restrictive and threatening" and directly affect the main through roads. An essential tool for the prevention of the collapsing traffic situation in the urbanized spaces is a comprehensive knowledge of the transport situation and the causes of the poor modal split. Why do we know so little about these issues? In this bad operational situation we still have the 
reconstruction of a section of a "main road" or an emergency situation of a water, sewage or gas network on that same road, and then the problem is unsolvable.

Persons responsible for the creation, development and/or maintenance of the city road network have solve systematically the traffic problems by the organisation and regulation tools of traffic. And we need to know the details! During the implementation of the new social conditions in our cities the lives of one of the active generation reflects the degradation of the complexity of social relations in dayto-day terms in an urbanized area. Of course, this is a basic requirement of life itself in the cities, which is defined by mobility relations. This base attribute corresponds to the quality of an urban space and its relationship to the people/citizens. This article will not analyse in detail the causes because it is a thing of the past; unfortunately, it is a political and administrative principle. The question of the construction of a roadway which is even more serious, will not be the subject of this analysis (especially not about building of new roads). Instead, it will focus on a description of the traffic engineering practice, why we are in this powerless state when it cames to the renewal of urban roads. We will try to respond to the attributes that are supported by the years of empirical experience of the authors, which can define as follows:

- What are the tools by which we can prevent road capacity problems?

- How we are starting to deal with the collapsing traffic situation?

- Why if we cannot improve them, can we not at least stabilize traffic conditions?

- How can we competently predict the collapse of "transport services" in the cities i.e. "mobility" because its sustainability of it in this case means only to "maintain" (keep) the present bad traffic situation?

- How can this state of affairs be changed, and what cities need to comprehensively implement a new approach for the quality of the development of "sustainable mobility" in all its fields of activity and responsibility?

\section{CITIES AND THEIR TRAFFIC PROBLEMS}

Why can we not find solutions to each of the points defined above in our cities? The simple answer to the first bullet in the introduction is that almost no city in Slovakia has a strategy or concept for the development of its communications network. They have not defined simple measurable goals on three levels:

1. Strategic - According to the building code the development that a city wants to reach in about $10-15$ years, has to be defined in a transport master plan (it is best to have it, confirmed and supplemented in the second year of a mandate of the city fathers in an election period,). We would like to mention that a sustainable urban mobility plan (SUMP) does not qualify as a transport master plan and cannot replace one, even though in general the state administration does make this effort.

2. Medium-term - what the city knows how to actually implement on its network for urban roads, which represents a stage of 5-8 years (but we can realise part of it during an election period, i.e., to start something at the end of a first period and continue it in a new period-we have 4-year election cycles in Slovakia).

3. Operational - a one-year term, which is what we actually already do with public procurement and handle most commonly by the renewal or reconstruction of specific sections of local roads (annually or after approval of the budget for the next year).
Let us see how our cities prepare annual reports on activities in the field of transport. If we have this document that is agreed to by the city council, a city can carry out its own preparations to implement what has been defined for a yearly time period; the city can ultimately keep control of all the activities and conduct them. This system can also regulate certain priorities, which, however, can only be on the level of one year. Otherwise we lost the goal.

We can conclude that the result is disorderly work, which should be continuous over time. The main problem of systemic work is that in our cities we do not have a comprehensive database of local roads with their technical parameterization, crossings, pavements, and equipment or engineering networks. According to the Road Act it is the responsibility of the road administration, and has been valid since the 1950s. We cannot find an answer as to why the cities still do not have this database. For example, if cities could have the results of transport surveys annually (in certain sections of the road network and some of the crossings, on which we could repeat a survey at intervals of 2-3 years), we would have an argumentative system of traffic loads for the local network. According to this base value of traffic growth we have a clear tool for reconstruction. In addition we can define the prioritization steps for example for bus lanes or bike paths in real time period.

\section{THE SOURCE OF THE DEGRADATION OF URBAN ROADS}

The second bullet above notes is that we are starting to notice a collapse of the traffic situation in our small towns. Why the small cities do not claim the responsible bodies - the Ministry of Transport (responsible for $1^{\text {st }}$ class roads) and regional governments $\left(2^{\text {nd }}\right.$ and $3^{\text {rd }}$ class roads) and their administration, who are responsible for a bad conditions on this roads and why they do not inform about the disproportions on these roads? The reason is that all through roads in these small towns belongs to the state or regions. Most of our towns and cities have some problems in common on through roads, i.e., national and regional roads, which do not belong to towns. Evaluations of the traffic conditions are conducted in rural areas and not in the cities.

Why does a road network degrade; what causes it; and do we have the expert technical and technological tools to remedy it? Then there is the issue of time limits, which is a technical problem. The knowledge of technical degradation of a road is the main reason that should start the processes for road reconstruction. Than we have to put to the planned time, in which time will be the reconstruction and finally we have to looking for financing. We think and we believe that the current state of a declarations about "the horrific quality of our road network" simply says means "we cannot confirm the financial coverage, but if we ever have it, then we will include it in a plan"! We cannot understand, however, that if we continue to put off the problem of reconstruction for the next decade into the future, then we really will not to have a need for any reconstruction. From a technical (construction) point of view, the road networks will fall apart. Let us not forget that for more than $40-50$ years, we have delayed taking any action.

Blame the cities that the system of road administration is as it is, but what we do not know at all, is why do we such a volume of transport on our roads? We cannot use the national census data on transportation as an excuse, because it is only a statistical sample and not a value for rehabilitating our road network.

The reader may notice that thus far we have not talked about any urban road network because as far as financing them from the taxes of our citizens there is certainly nothing to offer. The largest traffic volumes are on the borders of rural-urban road sections, they occur on a daily basis. The traffic flows, particularly in smaller towns and cit- 
ies, are not internal city centre traffic but usually through traffic. And this is a problem of the state and/or region. Some tools for preventing the degradation of urban road networks have been mapped out in different project outputs, which are sufficiently analysed in (Schlosser, 2015; Schlosser and Schlosser, 2009; Ondrovič and Schlosser, 2010; Schlosser and Schlosser, 2017; Schlosser et.al, 2017).

\section{IS IT POSSIBLE TO STABILISE THE REHABILITATION OF LOCAL ROADS UNDER OUR CONDITIONS?}

Each city manager and his team of engineers have a simple answer to the above question. Almost no city is unable to classify and quantify the value of the decomposition and degradation levels of the liquidation of its own urban road network. Simply put, the state of the roads has already been more or less destroyed and only after a lifetime of 15-20 years. What makes something a system? On the one hand, we have laws, standards, technical specifications, and a methodology for carrying out quality activities, but we do not have an answer anywhere that we can adhere to and apply. We should know about these rules and responsibility in the Road Act. Road administration activities can solve only some local defects on roads, and some sections of streets covering short distances in our cities. Is this a suitable solution? How do we start from the bottom of inadequate and possibly inappropriate solutions when creating high-quality road network? Why do cities not have sufficient potential to systemically address these problems and not just through the ad hoc voting in city councils?

We have too many questions concerning the definition of a "functional recovery system" for our roads. The answer is a simple "system", i.e., we need to know the current state of the road network describing these urban roads with measurable tools. The base parameter is a real and continuous traffic volumes on roads. If we do not start, we don't know how to create a "systemic approach" (pressure) on the transport policy of the State. This must be changed from the top and it certainly is not the way to cancel the State debt brake, what is nowadays a requirement of our Government to have a budget for realization of our state and regional road network. About the reconstruction of the roads we cannot to hear anything.

The head of the state defines how to achieve the quality of life for a society. If a higher quality of life in our society is not correctly defined by its infrastructure and its services, then we cannot solve the above questions at all. Each answer in the field road network maintenance is technically clear, what means that we have to have strictly measured parameters of the road quality. So we can only determine why and how to stabilize, rather than improve, the conditions of the road traffic through the reconstruction of our roads.

\section{CLASSIFICATION OF THE COLLAPSE OF THE “TRANSPORT SERVICES" IN THE CITIES}

We can determine the speed of the collapse very simple in time. We proceed from the idea that in each city has a readable investment activity. This involve new demands on the territory and thus also on its transport and services. At the same time there is a big "boom" in projects supported by the EU. Let us start to check the traffic situation through the upcoming projects. It allows us the present state of the traffic conditions and we need to fulfil the requirements of the Road Act as well as technical standards and regulations. We need to observe and require the required rules. For each project that is established on the territory of a city and has a size (the number of parking spaces on the basis of STN 73 6110), these basic elements should be required:
1. Define the size of the territory, which the investor must accept in its project. The city will define the urban perspective - where and what will be implemented, but this does not mean that a new investor has to include, in his project the entire urban network with all possible structures,

2. Carry out a traffic survey:

a. short-term - routing traffic at the relevant junctions and

b. long-term - a minimum of 2 to 4 weeks with automated counting devices,

3. Evaluate the traffic surveys according to Technical requirements TP 102 - pay attention to the modal split of the traffic flows and also to data on walking, cycling and public transport,

4. If the investment is large enough (as defined by STN standards), create a transport model for the present situation and compare it with the results of the long-term survey. Any deviation from the actual condition should not exceed $+/-10 \%-12 \%$,

5. Perform traffic scenarios with the model as well as assess uncontrolled and controlled junctions for the morning and afternoon traffic peaks, at 5 -minute intervals as determined by the long-term survey (details set out in the TP 102),

6. Define four basic scenarios (exactly according to TP 102) with the timeline:

a) the current status

b) the year when the investment will be ready, but without data of traffic volumes from this new investment;

c) the year when the investment will is already be in operation to demonstrate the "added value" of the new investment and a clear increase in the available network of urban roads and their junctions,

d) predictions - the view +10 years or +20 according to the regulations of each town,

7. The designer has to give the results from traffic surveys in an electronic form in order to get the town to insert them into its database. The city does not have the right to ask for a detailed output and transport model, because it is the subject to copyright law. The administration very often makes the mistake for public procurement works and contracts of not asking for a functional transport model together with its matrixes, which could be used for the town.

If towns have or try to create a database at least in this part of the traffic engineering, the data must be continuously collected over time. Towns can achieve the initial system solutions if they have the data for at least the last 5 years (from each year). Only then can a town competently declare some disproportions (differences) on its urban road network. We must not forget that the data in a database older than two years needs to be updated, because it loses its informative value.

\section{A NEW APPROACH FOR THE QUALITY OF "SUSTAINABLE MOBILITY"}

Defining the sufficient extent of the basic data for the reconstruction of a network of urban roads is a guarantee of a long-term process by which a town clearly knows how to define the "development of sustainable transport". It is never a one-off activity, which is currently based on a project financed by the EU. Unfortunately, we must conclude that the "dependence" of our cities "is bound to the "dependence" of our state on the EU. You can say that it is a disaster. According to a professional view, we can say that to be in such a chain of "dependencies", we cannot systemically set up a development of "sustainability". A number of rules from recent years, which we have obtained empirically, are defined in (Schlosser, 2015; Schlosser, 2016). So how can we continue? 
How to create a system in towns, which will be stabilized, and will go over several election periods without any engineering changes. It is, in fact, a second obstacle, where the towns cannot continuously develop, and this has taken more than a quarter century. If we admire Copenhagen or the Dutch cities and we see only cyclists in these towns, this is also a fundamental failure in defining the priorities for our cities. Unfortunately, challenges from our ministries do not take into account the complexity of the development of our towns. To be modern or a "smart city" means under our condition to "realize only pavements for cyclists". We should not forget that since 1960s, Copenhagen continually created a certain volume of the traffic surveys "annually" at critical locations, which changed over time. So it has a database of "life" all over the city expressed in the traffic volumes and classes of the traffic flows, as well as in the sharing of the modal split. Of course, since 1970s Copenhagen has strategically and systematically built up its present "sustainable mobility" in cycling as a mode of transport. However, we should not forget what in our terms and under our conditions is very often forgotten. Copenhagen with structured, systematic and continuous rules improves and builds its transport infrastructure for other types of transport as well. This means that the transport authority of the Copenhagen is building a road infrastructure for dynamic car transport as well as public transport. Compared to the network of public transport in Bratislava Copenhagen is very poor). Disparities between these cities are tremendous. For our capital of Bratislava the land-use plans have defined how to build and restore a transport communication network. The state government level let the priorities for cycling and cosmetic adjustments in the public transport only. In our conditions we cannot see, or better to say, we do not want to see how complex the support of the transport policy for Copenhagen is handled by the state. The differences are really large.

\section{CONCLUSION}

This article was aimed at starting a discussion concerning traffic engineering and planning and for the need for the preparation and recovery of local urban roads in towns, because if we had immediately connected all the principles requiring pavement elements in terms of the lifespan of a road, probably no one would read this article to the end. Such a large range of activities over in time is impossible to solve with a team of professionals, working in Slovak towns. Our towns do not have for this field of activity enough professionals. This we can confirm with certainty according to the actual situation in our towns.

The experiences, which are presented in this contribution, are based on more than 65 projects and studies. These are experiences of 15 years of activities with investors and city authorities throughout Slovakia. According to expert viewpoints, we would like to declare that the situation in traffic operations in our towns is at least stable. However, it can be stated that investors would like to have comprehensible and measurable system and are willing to proceed on the "added value" that our towns could start to create at least some space for the systemization of "sustainable mobility". Let us not forget that this can only be done with measurable quantities. What we can do when in the methodology about a sustainable urban mobility plan, the Ministry of Transport and Construction of the Slovak Republic declares that the parameter "mobility" is a non-dimensional number. Maybe there is something further to comment about?

The contribution was written with the support of the VEGA 1/0501/17 project Optimisation of the use of environmentally acceptable materials for traffic areas. 


\section{REFERENCES}

Borš, M., Nemec, N., Schlosser, T. (2017) The possibility of tramway layout on Fajnor riverbank Pribinova - Karadzicova in Bratislava (Možnosti vedenia električkovej trate v polohe Fajnorovo nábrežie - Pribinova - Karadžičova v Bratislave), XVIII. Traffic Engineering Days - Intelligent systems - transport, parking, public transport (Dopravně inženýrske dny - Inteligentní systémy - doprava, parkování, veřejná doprava), Česká silniční společnost' a Slovenská cestná spoločnost' (Czech Road Society and the Slovak Road Society), Mikulov, Czech Republic 2017, ISBN 978-80-270-1322-7.

Koštial, M., Schlosser, T., Schlosser, P. (2017) Development of Public Rail Track Transport in Nord-Western Area of Bratislava, In Procedia Engineering: World Multidisciplinary Civil Engineering-Architecture-Urban Planning Symposium 2017, WMCAUS 2017; Prague, Czech Republic; 12.6.-16.6.2017, Vol. 245, No. 4, 2017, online, ISSN: 17578981, Scopus, DOI: 10.1088/1757$899 \mathrm{X} / 245 / 4 / 042060$.

Ondrovič, P., Schlosser, T. (2010) Need of traffic engineering analyses for large investment projects and experiences from long term traffic surveys before and after putting them into operation - Motorway D1 model and the city of Zilina (Potreba dopravno-inžinierskych analýz pri vel'kých investičných projektoch a skúsenosti z dlhodobých dopravných prieskumov pred a po spustení do prevádzky - model dial'nica D1 a mesto Žilina), $7^{\text {th }}$ International conference - Traffic infrastructure in cities (Dopravná infraštruktúra v mestách), Faculty of Civil Engineering, University of Žilina, Slovakia 2010, ISBN 978-80-554-0254-3.

Pomichal, E., Schlosser, T., Bálint, G. (2017) Design of tramway line in Bratislava from the downtown to the area of Mlynske Nivy (Návrh trasy električkovej dopravy v zastavanom území Bratislavy z centra mesta do územia Mlynských nív), XVIII. Traffic Engineering Days - Intelligent systems - transport, parking, public transport (Dopravně inženýrske dny - Inteligentní systémy - doprava, parkování, veřejná doprava), Česká silniční společnost' a Slovenská cestná spoločnost' (Czech Road Society and the Slovak Road Society), Mikulov, Czech Republic 2017, ISBN 978-80-270-1322-7.

Schlosser, T. (2016) Alternative transport in MTP Bratislava - its place and extent in traffic engineering and land-planning documents (Alternatívne druhy dopráv v ÚGD Bratislavy - ich miesto a rozsah $\mathrm{v}$ dopravno-inžinierskej a územno-plánovacej dokumentácii), XVII. Traffic Engineering Days (Dopravně inženýrske dny - Zklidnění dopravy ve městech a obcích, Česká silniční společnost' a Slovenská cestná spoločnost' (Czech Road Society and the Slovak Road Society), Mikulov, Czech Republic 2016, ISBN 978-80-260-9662-7.

Schlosser, T. (2015) Modal split in Bratislava (Del'ba prepravnej práce v Bratislave), XVI. Traffic Engineering Days (Dopravně inženýrske dny), Česká silniční společnost' a Slovenská cestná spoločnost' (Czech Road Society and the Slovak Road Society), Mikulov, Czech Republic, 2015.

Schlosser, T. (2015) Traffic organisation and regulation as a base attribute of mobility development (Organizácia a regulácia dopravy ako základný atribút rozvoja mobility), International conference on Public Transport (Verejná osobná doprava), Kongres Studio, Bratislava, Slovakia 2015.
Schlosser, T., Orthová, M. (2016) Experiences from Project of Carrying Public Transport System in Bratislava, In TRINfra 2016. Trends and Innovations in Transport Infrastructure, proceedings of the International Students' Scientific Conference. Prague, Czech Republic, 20. 6. 2016, 1st ed.: Czech Technical University in Prague, Faculty of Civil Engineering, 2016, pp. 29-36. ISBN 978-80-01-05973-9.

Schlosser, T., Schlosser, P. (2017) Experiences from the traffic modelling for decision making on tramway lines for a new city centre in Bratislava (Skúsenosti z tvorby dopravného modelu pre rozhodovaci proces návrhu električkových trati pre nové centrum Bratislavy), 9th International Conference on Dopravná infraštruktúra v mestách, PTV VISION seminar, University of Žilina, Slovakia, 3. - 4. 10 2017. 1st ed. Žilina: EDIS, 2017, USB key, ISBN 978-80-554-1370-9.

Schlosser, T., Schlosser, P. (2016) New Tramway Infrastructure in Bratislava - How Can Influence the Well Prepared Traffic Engineering Analysis and Planning Tools the Decision Making, In Procedia Engineering: World Multidisciplinary Civil Engineering-Architecture-Urban Planning Symposium 2016, WMCAUS 2016. Prague, Czech Republic 13. - 17. 6. 2016. Vol. 161, (2016), online, pp. 247-252. ISSN 1877-7058. SCOPUS; WOS; DOI: 10.1016/j.proeng.2016.08.545

Schlosser, T., Schlosser, P. (2009) Traffic surveys and traffic modelling in Slovak cities (Dopravné prieskumy a modelovanie dopravy v mestách SR), International ROSALINE 09 conference, Bratislava, Slovakia 2009.

Schlosser, T., Schlosser, P., Cápayová S., Hodáková, D. (2017) Complex traffic analysis of new downtown of Bratislava for environmental assessment, In SGEM 2017. 17th International Multidisciplinary Scientific GeoConference. Vol. 17. Energy and Clean Technologies: conference proceedings. Albena, Bulgaria, 29 June - 5 July 2017. 1st ed. Sofia: STEF 92 Technology, 2017, pp. 399-407. ISSN 1314-2704. ISBN 978-619-7408-06-5. SCOPUS; DOI: 10.5593/sgem2017/41/S19.051.

Schlosser, T., Schlosser, P., Cápayová S., Hodáková, D. (2017) Terminals for Suburb Bus Transport in Bratislava, In Procedia Engineering: World Multidisciplinary Civil Engineering-Architecture-Urban Planning Symposium 2017, WMCAUS 2017; Prague, Czech Republic; 12.6.-16.6.2017, Vol. 245, No. 4, 2017, online, ISSN: 17578981, Scopus DOI: 10.1088/1757-899X/245/4/042059.

Schlosser, T., Schlosser, P., Schlosser, M. (2017) Can ITS applications help in the new city centre of Bratislava? (Pomôžu aplikácie IDS v novom centre mesta Bratislavy?) XVIII. Traffic Engineering Days - Intelligent systems - transport, parking, public transport (Dopravně inženýrske dny - Inteligentní systémy - doprava, parkování, veřejná doprava), Česká silniční společnost' a Slovenská cestná spoločnost' (Czech Road Society and the Slovak Road Society), Mikulov, Czech Republic 2017, ISBN 978-80-270-1322-7.

Schlosser, T., Zuzulová, A., Cápayová S., Schlosser, P. (2016) New public transport tramway line in Bratislava - Way of improving the environmental conditions, In SGEM 2016. 16th International Multidisciplinary Scientific GeoConference. Book 4. Energy and Clean Technologies: conference proceedings. Albena, Bulgaria, 30 June - 6 July 2016. 1. ed. Sofia: STEF 92 Technology, 2016, pp. 475-482. ISSN 1314-2704. ISBN 978-619-7105-64-3, WOS:000391348700061. 